\title{
外部PC鋼棒により横補強されたRC柱の付着割裂破壊の影響を受ける せん断強度に関する実験的研究 \\ EXPERIMENTAL STUDY ON SHEAR STRENGTH AFFECTED BY SPLITTING BOND FAILURE OF R/C COLUMNS STRENGTHENED LATERALLY WITH EXTERNAL PC RODS
}

\author{
黒木正幸*1, 菊池健児*2, 崎野健治*3, 山川哲 雄*4 \\ Masayuki KUROKI, Kenji KIKUCHI, Kenji SAKINO \\ and Tetsuo YAMAKAWA
}

\begin{abstract}
This paper aims to investigate the shear strength, which is affected by splitting bond failure of the longitudinal rebars, of the R/C columns laterally strengthened with external PC rods. The results of cyclic loading tests indicate that the shear strength is much higher than that of predictions by an existing method based on the combination of truss and arch mechanisms. The shear strength can be predicted better if the effect of cover concrete on the bond stress of longitudinal re-bars required in the truss mechanism is taken into account.
\end{abstract}

Keywords: Shear strength, Splitting bond failure, Prestress, Seismic retrofit せん断強度, 付着割裂破壊, プレストレス, 耐震補強

1. はじめに

Burdette と Hilsdorfは, 円形横拘束コンクリートの圧縮性状と角 形のそれの違いに着目し,角形柱における横補強筋を断面の四隅に 外側から当てた山形鋼と外部鋼棒で理想的に置き換えた柱試験体に 対して中心圧縮実験を行い, 横拘束力の分布がコンクリートの圧縮 性状に及ぼす影響を検討した ${ }^{1)}$ 。

筆者らは，既存鉄筋コンクリート（RC）造柱断面の四隅に鋼製 コーナーブロックを配置し,これらに架け渡されたPC鋼棒を緊張し て柱を能動的に横拘束する耐震補強法の研究を行っている。本補強 法の施工上の利点は, 火気およびモルタルや接着材を基本的に必要 としないこと,耐震壁の側柱や二次壁付き柱にも,壁に穴を開ける だけで適用できることである。一方, 力学的な特徴は補強材である $\mathrm{PC}$ 鋼棒が高強度であることと,これに初期緊張力を導入し既存柱を 能動的に横拘束することである。その効果に関しては,例えば柱の 中心圧縮実験 ${ }^{2}$ によれば, 能動横拘束力の存在は圧縮強度の増大に 効果があることが示されている。また, $\mathrm{PC}$ 鋼棒は柱の圧縮強度時に 降伏せず, その後も横拘束力が増大し続けるため, 柱の圧縮勒性能 の改善に効果があることが示されている。

本論文では, 外部PC鋼棒により横補強された柱の付着割裂破壊時 のせん断力 (本論では付着割裂破壊の影響を受けるせん断強度と称 す)の把握を目的として行った研究について報告する。本論文の前
段では,材長が短く,比較的多量のPC鋼棒により外部横補強された 柱の曲げせん断実験の概要と結果を示す。後段では, 文献3）で得 られた算定式による主筋の付着割裂強度を用い, 付着割裂破壊の影 響を受けるせん断強度の算定法について検討する。

\section{2. 試験体}

表 1 に試験体の一覧を示し,図 1 に試験体の形状・寸法と配筋状 況を示す。試験体の柱断面寸法（幅 $b \times$ せい $D$ ) は $250 \mathrm{~mm} \times 250 \mathrm{~mm}$, 柱内法高さ $L$ は $500 \mathrm{~mm}$ で, 形状比 $L / D$ は 2.0 である。横補強筋（帯 筋）は $\$ 4 @ 100 \mathrm{~mm}$ で, 横補強筋比 $p_{w}$ は $0.10 \%$ である。外部 PC 鋼 棒 (直径 $5.4 \mathrm{~mm}$ ) の配置間隔は $50 \mathrm{~mm}$ で, $\mathrm{PC}$ 鋼棒による横補強筋比 $p_{w p c}$ は $0.37 \%$ である。PC鋼棒はコンクリート表面には接触しておら ず，両者間には $3 \mathrm{~mm}$ の隙間がある。PC鋼棒による横拘束力は柱断 面の四隅に配置された鋼製コーナーブロックにより導入される。

試験体数は柱主筋が 12-D13のもの5体と, 8-D13のもの1体の計 6体である。実験変数は中段主筋の有無, 軸方向応力度 $\sigma_{0}$ の大きさ, $\mathrm{PC}$ 鋼棒の初期導入ひずみ度 $\varepsilon_{p c 0}$ の大きさである。表 1 の $\sigma_{r}$ は $\mathrm{PC}$ 鋼 棒の初期緊張力による横拘束力がコンクリート表面に一様に分布す るとみなした場合の平均側圧 (以下, 能動側圧) を表している。

表 2 に鉄筋とPC鋼棒の力学的性質を示す。主筋に用いた異形鉄 笳はふしが材軸に対して直交しているもので, コンクリートとの付
*1 大分大学工学部福祉環境工学科建築コース 助教 $\cdot$ 工修

*2 大分大学工学部福祉環境工学科建築コース 教授. 工博

*3 九州大学大学院人間環境学研究院 教授・工博

*4 琉球大学工学部環境建設工学科 教授.工博
Research Assoc., Dept. of Architecture, Oita Univ., M. Eng.

Prof., Dept. of Architecture, Oita Univ., Dr. Eng.

Prof., Faculty of Human Environment Studies, Kyushu Univ., Dr. Eng.

Prof., Dept. of Civil Eng. and Architecture, Univ. of the Ryukyus, Dr. Eng. 
表1＼cjkstart試験体の諸元と実験結果の一覧

\begin{tabular}{|c|c|c|c|c|c|c|c|c|c|c|c|c|c|c|c|}
\hline \multirow{3}{*}{ 試験体 } & \multicolumn{9}{|c|}{ 諸元 } & \multicolumn{6}{|c|}{ 実験結果 } \\
\hline & \multirow{2}{*}{ 主筋量 } & \multirow{2}{*}{$\begin{array}{c}\sigma_{0} \\
\left(\mathrm{~N} / \mathrm{mm}^{2}\right)\end{array}$} & \multirow{2}{*}{$\begin{array}{c}\varepsilon_{p c 0} \\
\left(\times 10^{-6}\right)\end{array}$} & \multirow{2}{*}{$\begin{array}{c}\sigma_{r} \\
\left(\mathrm{~N} / \mathrm{mm}^{2}\right)\end{array}$} & \multirow{2}{*}{$\begin{array}{c}\sigma_{B} \\
\left(\mathrm{~N} / \mathrm{mm}^{2}\right)\end{array}$} & \multirow{2}{*}{$\begin{array}{c}\sigma_{t} \\
\left(\mathrm{~N} / \mathrm{mm}^{2}\right)\end{array}$} & \multirow{2}{*}{$\frac{Q_{s u}}{Q_{m u}}$} & \multirow{2}{*}{$\frac{Q_{b u}}{Q_{m u}}$} & \multirow{2}{*}{$\frac{\tau_{b u}}{\tau_{f}}$} & \multirow{2}{*}{$\begin{array}{l}Q_{s c} \\
(\mathrm{kN})\end{array}$} & \multicolumn{2}{|c|}{$Q_{\max }(\mathrm{kN})$} & \multicolumn{2}{|c|}{$R_{u}\left(\times 10^{-2} \mathrm{rad}\right)$} & \multirow{2}{*}{$\begin{array}{l}\text { 破壊 } \\
\text { モード }\end{array}$} \\
\hline & & & & & & & & & & & 正加力 & 負加力 & 正加力 & 負加力 & \\
\hline M-01 & \multirow{5}{*}{$\begin{array}{l}\text { 12-D13 } \\
\text { (多段) }\end{array}$} & 0 & 1,225 & 0.92 & 19.5 & 1.92 & 1.25 & 0.96 & 0.70 & 98 & 205 & 200 & $>5.0$ & $>5.0$ & $\mathrm{~F}$ \\
\hline M-30 & & \multirow{3}{*}{3.15} & 75 & 0.06 & 19.4 & 1.89 & 1.01 & 0.67 & 0.47 & 145 & 228 & 219 & 3.2 & 2.8 & S \\
\hline M-31 & & & 1,225 & 0.92 & 21.1 & 2.00 & 1.06 & 0.80 & 0.65 & 175 & 256 & 263 & 4.4 & 4.3 & $F_{y}-S$ \\
\hline M-32 & & & 2,450 & 1.85 & 20.6 & 1.87 & 1.05 & 0.91 & 0.81 & 197 & 264 & 261 & 5.0 & 4.6 & $F_{y}-S$ \\
\hline M-61 & & 6.30 & 1,225 & 0.92 & 18.6 & 1.99 & 0.93 & 0.72 & 0.62 & 207 & 272 & 256 & 2.9 & 2.9 & S \\
\hline S-61 & 8-D13 & 6.30 & 1,225 & 0.92 & 19.1 & 2.13 & 0.98 & 0.75 & 0.62 & 201 & 267 & 274 & 4.0 & 3.6 & $F_{y}-S$ \\
\hline
\end{tabular}

備考） $\sigma_{0}$ : 軸方向圧縮応力度, $\varepsilon_{p c 0}$ : $\mathrm{PC}$ 鋼棒の初期ひずみ度, $\sigma_{r}$ : 能動側圧 $=E_{p c} \cdot \varepsilon_{p c 0} \cdot 2 a_{p c} /\left(b \cdot s_{p c}\right), E_{p c}$ : PC 鋼棒の弾性係数, $a_{p c}: \mathrm{PC}$ 鋼棒一本の断面積, $s_{p c}$ : PC 銅棒の配置間隔, $\sigma_{B}$ と $\sigma_{t}$ : コンクリートシリンダーの圧縮強度と割裂強度, $Q_{s u}$ : 勒性指針式によるせん断強度計算值, $Q_{b u}$ : 勒性指針式によ る付着割裂破壞の影響を考慮したせん断強度計算値 ( $\cot \phi=1.0$ とした場合), $Q_{m u}: \mathrm{ACI}$ ストレスブロックを用いた曲げ終局強度時せん断力計算值, $\tau_{b u}$ : 式 1 6による主筋群の付着割裂強度, $\tau_{f}: Q_{m u}$ 時における危険断面の主筋軸力から有効付着長さを $L-d$ として評価した付着応力度, $Q_{s c}$ : せん 断ひび割れ強度, $Q_{\max }$ : 最大荷重, $R_{u}$ : 限界部材角, $\mathrm{F}:$ 曲げ破壊, $\mathrm{S}:$ せん断破壊, $\mathrm{F}_{\mathrm{y}}-\mathrm{S}:$ 曲げ降伏後のせん断破壊
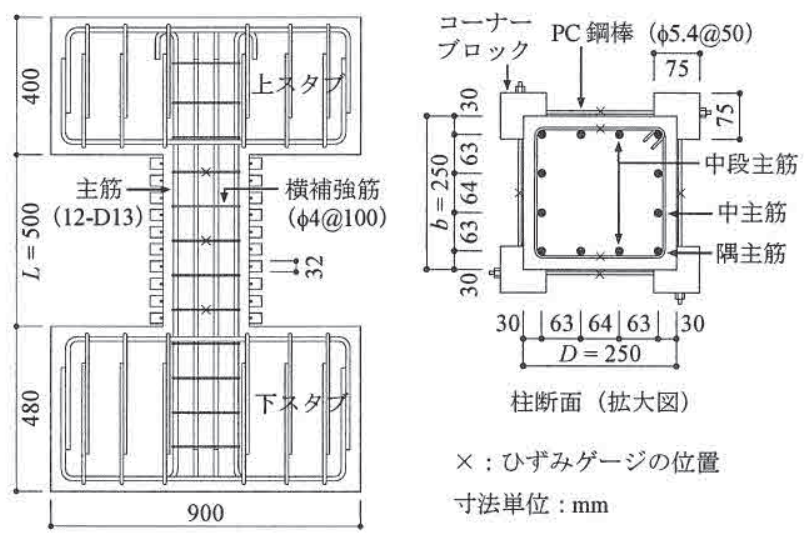

$\times:$ ひずみグージの位置

寸法単位 : $\mathrm{mm}$

図1＼cjkstart試験体の形状・寸法と配筋状況

表2 鉄筋と PC鋼棒の力学的性質

\begin{tabular}{|l|c|c|c|c|c|}
\hline 種類 & $\begin{array}{c}\text { 断面積 } \\
\left(\mathrm{mm}^{2}\right)\end{array}$ & $\begin{array}{c}\text { 降伏点強度 } \\
\left(\mathrm{N} / \mathrm{mm}^{2}\right)\end{array}$ & $\begin{array}{c}\text { 引張強度 } \\
\left(\mathrm{N} / \mathrm{mm}^{2}\right)\end{array}$ & $\begin{array}{c}\text { 弹性俰数 } \\
\left(\mathrm{kN} / \mathrm{mm}^{2}\right)\end{array}$ & $\begin{array}{c}\text { 破断伸び } \\
(\%)\end{array}$ \\
\hline $\mathrm{D} 13$ (主筋) & 127 & 339 & 474 & 183 & 27.6 \\
\hline$\phi 4$ (横補強筋) & 12.1 & $558 *$ & 657 & 201 & 10.3 \\
\hline$\phi 5.4$ (PC鋼棒) & 22.9 & $1,034 *$ & 1,115 & 206 & 測定せず \\
\hline
\end{tabular}

* $0.2 \%$ オセット法による

着に関する特性値 ${ }^{4)}$ はせん断面積係数 $S A$ 0.85 , 支圧面積係数 $B A$ が 0.076 である。コンクリートのシリンダー圧縮強度 $\sigma_{B}$ と割裂強度 $\sigma_{t}$ は, 表 1 に示すとおりである。コンクリートは, 粗骨材の最大寸 法が $10 \mathrm{~mm}$ のものである。

勒性指針式 ${ }^{5)}$ によるせん断強度 $Q_{s u}$ と付着割裂破壊の影響を考虑 したせん断強度 $Q_{b u}$ を算定し, $\mathrm{ACI}$ のストレスブロックを用いた曲 げ終局強度 ${ }^{6)}$ 時せん断力 $Q_{m u}$ で基準化したものを表 1 に示す。こ こで, $Q_{s u}$ と $Q_{b u}$ の算定において, トラス機構の有効係数 $\lambda$ は 1.0 と した。また, $Q_{s u}$ の算定では, $\mathrm{PC}$ 鋼棒は横補強筋とみなし, 降伏点 強度 $\sigma_{p c y}$ を用いた。 $Q_{b u}$ の算定では, $\cot \phi$ は $Q_{b u}$ が最も高く算定さ れる1.0とし例えば7), 主筋の付着割裂強度 $\tau_{b u}$ は文献3) で得られた 式 1 〜により評価した。

$$
\begin{aligned}
& \tau_{b u}=\left(0.17 \gamma_{b}+0.83\right) \tau_{b \max (\mathrm{wav})} \\
& \tau_{b \max }=\tau_{c o}+\tau_{a c}+\tau_{p a} \quad\left(\text { ただし, } \tau_{b \max } \leqq \tau_{p o}\right. \text { である) }
\end{aligned}
$$

$$
\tau_{c o}=1.22\left(0.0961 b_{s i}+0.134\right) \sqrt{\sigma_{B}}
$$$$
\tau_{a c}=\left\{\begin{array}{l}
0.508 \cdot \sigma_{c 0}(\text { 隅主筋に対して }) \\
0.238 \cdot \sigma_{c 0}(\text { 中主筋に対して })
\end{array}\right.
$$

$$
\tau_{p a}=\left\{\begin{array}{l}
16.5\left(1-\frac{\sigma_{c 0}}{\sigma_{c p . i}}\right) q_{t r}+12.3\left(1-\frac{\sigma_{c 0}}{\sigma_{c p . c}}\right) q_{p c}(\text { 隅主筋に対して }) \\
10.7\left(1-\frac{\sigma_{c 0}}{\sigma_{c p . i}}\right) q_{t r}+5.51\left(1-\frac{\sigma_{c 0}}{\sigma_{c p . c}}\right) q_{p c} \text { (中主筋に対して) }
\end{array}\right.
$$

$$
\sigma_{c p}=\left\{\begin{array}{l}
\left(\tau_{p o}-\tau_{c o}\right) / 0.508\left(\text { 隅主筋に対して, }=\sigma_{c p . c}\right) \\
\left(\tau_{p o}-\tau_{c o}\right) / 0.238\left(\text { 中主筋に対して, }=\sigma_{c p . i}\right)
\end{array}\right.
$$

ここに, $\gamma_{b}$ は中主筋付着強度 $\tau_{b \max }$ の隅主筋のそれに対する比, $\tau_{b \max (\mathrm{wav})}$ は隅主筋と中主筋の付着強度の加重平均値, $\tau_{c o}$ は横補強 筋と外部 PC 鋼棒がない場合の付着割裂強度, $\tau_{a c}$ はPC鋼棒の能動 拘束による付着強度増分, $\tau_{p a}$ は割裂ひび割れ発生後の横補強筋と $\mathrm{PC}$ 鋼棒の受動拘束による付着強度増分である。 $b_{s i}$ は全割裂モードの 割裂線長さ比 $=\left(b-n d_{b}\right) /\left(n d_{b}\right), n$ と $d_{b}$ は主筋の本数と直径, $\sigma_{c 0}$ は主筋 能動拘束応力度 $=\sigma_{r} \cdot b /\left(n d_{b}\right), \sigma_{c p}$ は主筋が割裂破壊するか引抜け破壊 寸る境界の能動拘束応力度, $q_{t r}$ は横補強筋に関する受動拘束基本因子 $=p_{w} b /\left(n d_{b}\right) \cdot \sqrt{\sigma_{B}}, q_{p c}$ はPC鋼棒に関する受動拘束基本因子 $=p_{w p c} b /$ $\left(n d_{b}\right) \cdot \sqrt{\sigma_{B}}, \tau_{p o}$ は主筋が引抜け破壊する場合の付着強度 $=0.60 \sigma_{B} \cdot S A$ である。なお, $\left(1-\sigma_{c 0} / \sigma_{c p . i}\right)$ と $\left(1-\sigma_{c 0} / \sigma_{c p . c}\right)$ は非負である。

計算結果はすべての試験体において $Q_{b u}<Q_{s u}$ であり, $Q_{b u} / Q_{m u}$ は $0.67 \sim 0.96$ である。また, $Q_{m u}$ 時における危険断面の主筋軸力から, 有効付着長さを $L-d(d$ : 有効せい $=220 \mathrm{~mm})$ として評価した付着 応力度 $\tau_{f}$ に対する $\tau_{b u}$ の比は $0.47 \sim 0.81$ である。

\section{3. 実験方法}

図 2 に実験装置を示す。鉛直方向の油圧ジャッキにより所定のー 定軸力を載荷し, 柱の中央高さに設置した水平方向の複動油圧 ジャッキにより静的繰返しの水平荷重を載荷した。水平荷重の載荷 は, 表 3 に示す載荷プログラムによった。変位測定項目は, 上下ス タブ間の水平変位と鉛直変位である。ひずみ測定項目は,すべての $\mathrm{PC}$ 鋼棒と図 1 に示す位置における横補強筋の軸方向ひずみ度であ る。なお, 主筋の付着性能に影響を及ぼす可能性のあるものを極力 なくすため, 主筋のひずみ測定は行わなかった。 


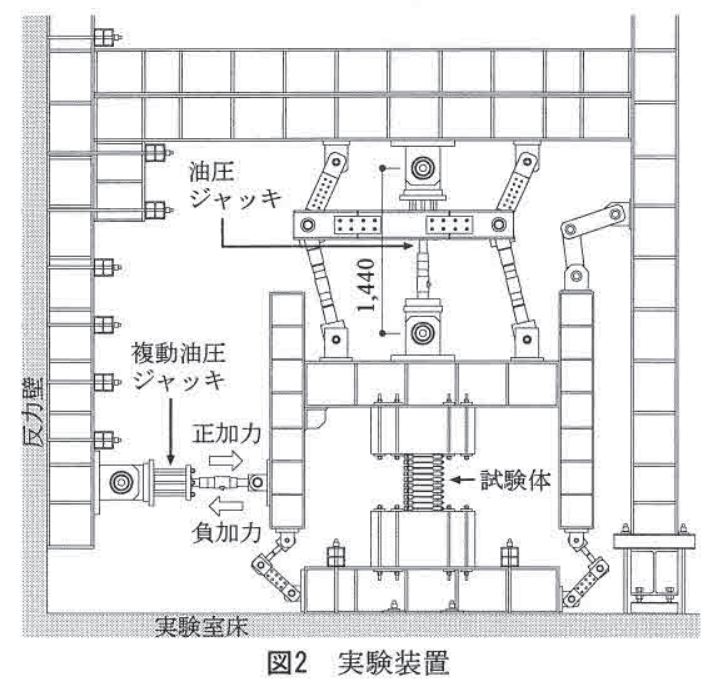

表3 繰返し水平荷重の載荷プログラム

\begin{tabular}{|c|c|c|c|c|c|c|c|c|c|c|c|c|c|c|}
\hline サイクル & 1 & 2 & 3 & 4 & 5 & 6 & 7 & 8 & 9 & 10 & 11 & 12 & 13 & 14 \\
\hline $\begin{array}{c}\text { 目標柱部材角 } \\
\left(\times 10^{-2} \mathrm{rad}\right)\end{array}$ & \pm 0.25 & \pm 0.5 & \pm 1.0 & \pm 2.0 & \pm 3.0 & \pm 4.0 & \pm 5.0 \\
\hline
\end{tabular}

\section{4. 実験結果}

4. 1 荷重変形関係と破壊性状

図 3 に水平荷重 $Q$ と柱部材角 $R$ の関係を示し, 図 4 に柱軸方向の 変形量 $\delta_{v}$ と柱部材角 $R$ の関係を示す。また, 図 5 に最終ひび割れ
状況を示す。図 3 には前述した $Q_{m u}, Q_{s u}, Q_{b u}$ を示す。日高らは, $\mathrm{PC}$ 鋼棒により外部横補強された柱断面の曲げ強度は, 主筋の降伏強 度と矩形のコンクリート圧縮応カブロックを用いた全塑性曲げモー メントで概ね評価できることを示している ${ }^{8)}$ 。そこで, 圧縮応力ブ ロックの強度は中田らの提案式 2 ) で評価し, 全塑性曲げモーメント に対するせん断力 $Q_{m p}$ を算定した。その結果も図 3 に示す。

いずれの試験体も曲げひび割れの発生後にせん断ひび割れが発生 したが, その後も水平荷重が増大した。柱幅の面では中主筋に沿う ひび割れが見られたが, 隅主笳に沿う付着割裂ひび割れは柱幅の面, 柱せいの面ともに見られなかった。

軸方向応力度 $\sigma_{0}$ が零の試験体M-01は, 材軸方向の伸びが顕著で あり水平耐力も安定していることから,曲げ破壊したと考えられる。

試験体M-30, M-31, M-32は $\sigma_{0}=3.15 \mathrm{~N} / \mathrm{mm}^{2}$ の条件で能動側圧 $\sigma_{r}$ の大きさが異なる試験体である。 $\sigma_{r}$ がほぼ零の試験体M-30は, コ ンクリートの損傷が顕著で最大水平荷重時において軸方向変形もほ とんどないことから，せん断破壊したと考えられる。試験体M-31， M-32は, 曲げ降伏後にせん断破壊したと考えられる。試験体M-30に 比べ試験体M-31, M-32の最大荷重が高く,これは能動側圧を与える とせん断強度が増大することを示している。

$\sigma_{0}=6.30 \mathrm{~N} / \mathrm{mm}^{2}$ で $\sigma_{r}=0.92 \mathrm{~N} / \mathrm{mm}^{2}$ の試験体M-61は, せん断破壊し たと考えられる。最大荷重は $\sigma_{0}=3.15 \mathrm{~N} / \mathrm{mm}^{2}$ の条件で曲げ降伏後に せん断破壊した試験体M-31のそれとあまり違わない。

中段主筋なしの試験体S-61は,曲げ降伏後にせん断破壊したと考

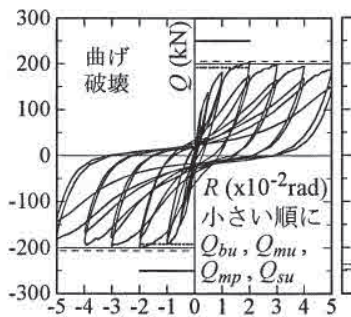

(a) 試験体 M-01

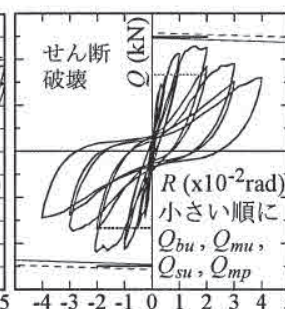

(b) 試験体 M-30

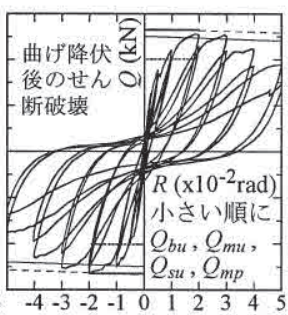

(c) 試験体 M-31

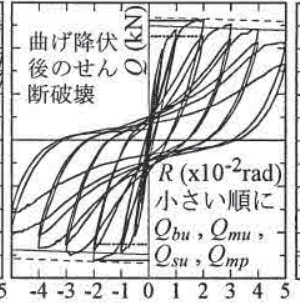

(d) 試験体 M-32

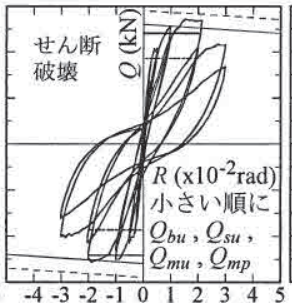

(e) 試験体 M-61

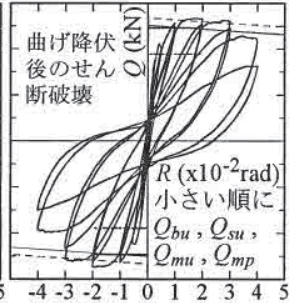

(f) 試験体 S-61

図 3 水平荷重 $Q$ と柱部材角 $R$ の関係

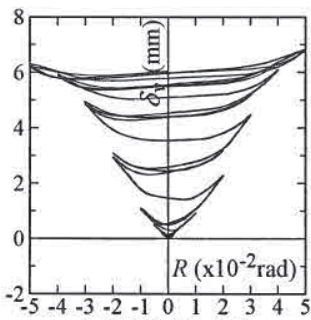

(a) 試験体 M-01

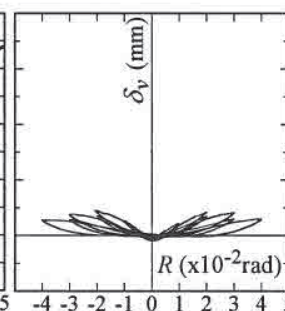

(b) 試験体 M-30

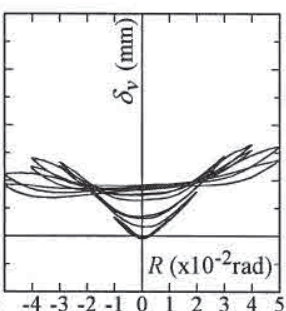

(c) 試験体 $\mathrm{M}-31$

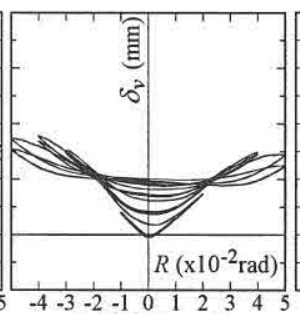

(d) 試験体 M-32

図4 軸方向変形量 $\delta_{v}$ と柱部材角 $R$ の関係

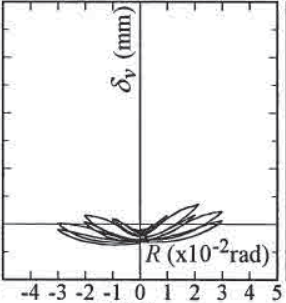

(e) 試験体 M-61

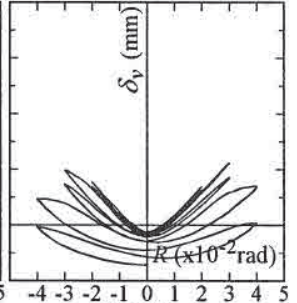

(f) 試験体 S-61

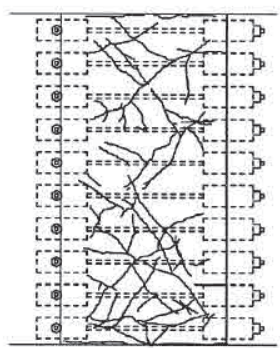

(a) 試験体 M-01

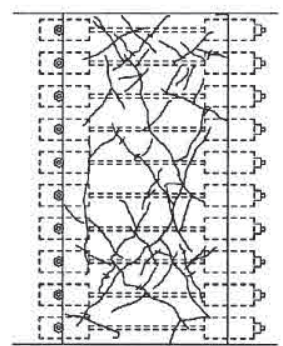

(b) 試験体 M-30

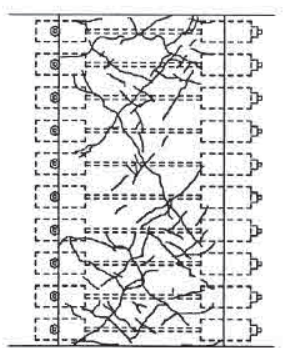

(c) 試験体 M-31

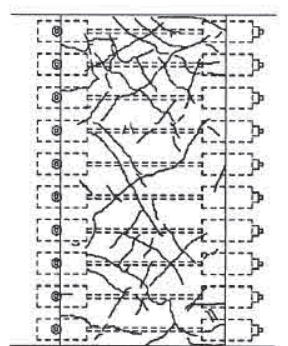

(d) 試験体 M-32

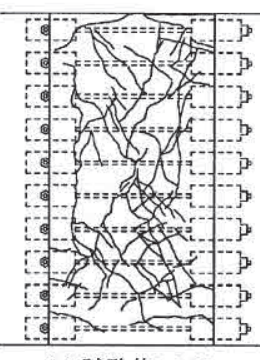

(e) 試験体 M-6

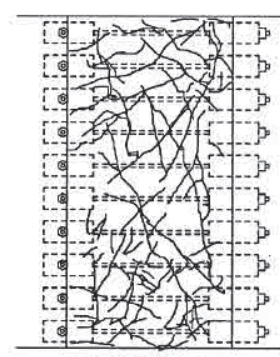

(f) 試験体 S-61

図5 最終ひび割れ状況（柱せいの面） 


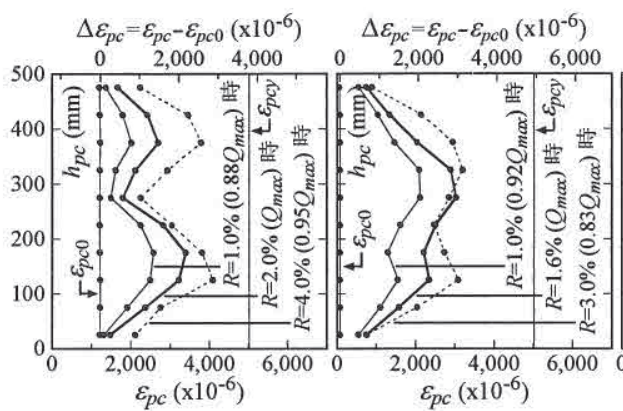

(a) 試験体 M-01

(b) 試験体 $\mathrm{M}-30$

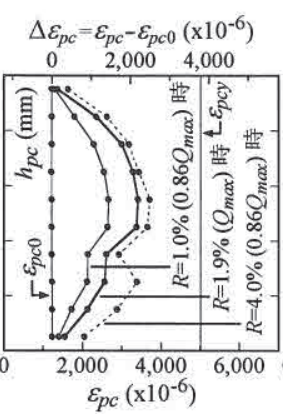

(c) 試験体 M-31

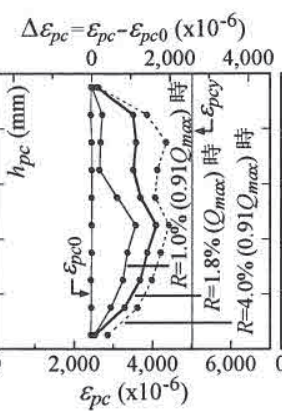

(d) 試験体 M-32

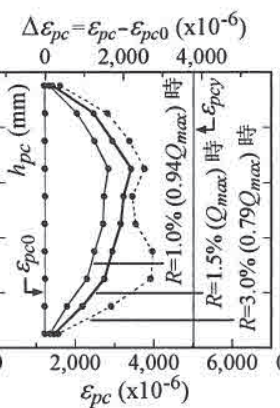

(e) 試験体 M-61

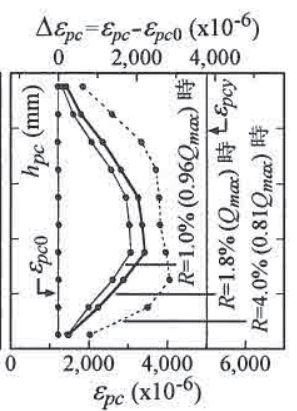

(f) 試験体 S-61

図6 柱せいの面のPC鋼棒ひずみ度 $\varepsilon_{p c}$ の高さ方向分布

えられる。最大荷重は, せん断破壊した中段主筋ありの試験体M-61 と同程度となっている。

表 1 にせん断ひび割れ強度 $Q_{s c}$, 最大荷重 $Q_{\max }$, 限界部材角 $R_{u}$, 破壊モードを示す。ここで, $R_{u}$ は $Q-R$ 関係包絡線において, 荷重 が $0.8 Q_{\max }$ に低下した時点の部材角である。

\section{4. $2 \mathrm{PC}$ 鋼棒のひずみ}

図 6 に柱せいの面のPC鋼棒ひずみ度 $\varepsilon_{p c}$ の高さ方向分布を示す。 ここで, $\varepsilon_{p c}$ は同じ高さに位置する 2 本の平均値である。曲げ破壞 した試験体M-01では, 柱中央高さ付近のPC鋼棒のひずみ度はあま り増加しておらず,柱材端から柱せいの半分ほど離れた位置におい てPC鋼棒のひずみ度増加が顕著である。一方, 曲げ降伏後にせん断 破壊した試験体M-31, M-32, S-61 とせん断破壊した試験体M-30, M-61では, 柱中央高さ付近のPC鋼棒のひずみ度増加が顕著である。 また, せん断破壊した試験体M-30, M-61の柱中央高さ付近にある $\mathrm{PC}$ 鋼棒のひずみ度を比較すると, 初期ひずみ度が大きい試験体 $\mathrm{M}-61$ ほうが, 最大荷重時のひずみ度増分 (図 6 の上側の横軸) は小さく なっている。なお, すべての試験体のPC鋼棒ひずみ度は, 実験終了 まで降伏ひずみ度 $\varepsilon_{p c y}\left(=\sigma_{p c y} / E_{p c}\right)$ 以下であった。

図 7 に最大荷重時における柱せいの面と柱幅の面のPC鋼棒ひず み度をならべて示す。ここで, 図に示しているのは下から 5 段, 6 段目 (柱中央高さ付近) の $\mathrm{PC}$ 鋼棒ひずみ度の平均值である。なお, 曲げ破壊した試験体M-01については, 下から 3 段目のひずみ度も 示す。水平荷重の載荷により,柱幅の面のPC鋼棒でもひずみ度の増 加がみられる。柱せいの面のひずみ度増分に対する柱幅面のそれは, せん断破壊した試験体M-30, M-61で 68〜 74\%, 曲げ降伏が先行し た試験体 M-31，M-32，S-61 で 40〜 49\%であった。

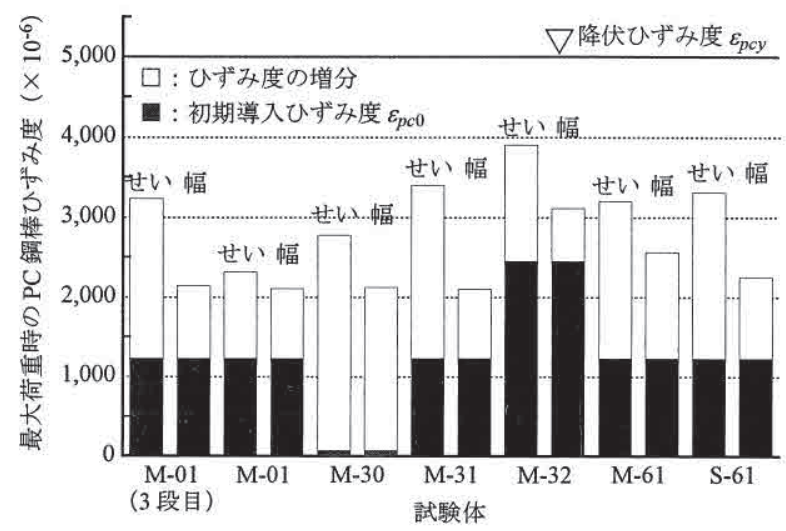

図7最大荷重時における柱せいの面と柱幅の面のPC鋼棒ひずみ度

\section{5 . 付着割裂破壊の影響を受けるせん断強度の検討}

\section{1 検討の概要}

本論では付着割裂破壊先行の実験を計画 $\left(Q_{s u} / Q_{m u}=0.93 \sim 1.25\right.$, $\left.Q_{b u} / Q_{m u}=0.67 \sim 0.96\right)$ したが, すべての試験体で顕著な付着割裂ひ び割れは観察されず,ほとんどの試験体は曲げ降伏の前あるいは後に $\mathrm{PC}$ 鋼棒が降伏することなくせん断破壊した。これはせん断強度や曲 げ強度が計算值よりも特に低かったわけではなく, 付着割裂破壊の影 響を受けるせん断強度が計算值よりも高かったためである。また, 柱 を能動横拘束するとせん断強度が増大することが示された。

ここでは,まずこのような実験結果について考察する。5.2〜5.6 節で, 横補強筋と PC鋼棒の引張力, 外側主筋間コンクリートの斜め 圧縮束, 主筋の付着力により構成されるトラス機構に,かぶりコン クリートの応力負担を考慮したせん断力伝達モデルによりせん断強 度を算定し, 実験結果と比較検討する。このモデルでは, ひび割れ 直交方向の平均ひずみ度に依存するコンクリート圧縮強度の有効係 数を用いる。また, 主筋の付着割裂強度はせん断ひび割れに起因す る横補強筋と $\mathrm{PC}$ 鋼棒の引張力増大の影響を受けるとする。

次いで, 5.7節では付着割裂破壊の影響を受けるせん断強度の算 定精度を比較的簡便に改善する方法について検討する。

\section{2 せん断カ伝達モデル}

市之瀬は, 圧縮軸力がある場合,かぶりコンクリート部にも斜め 圧縮束が形成され,これが外側主筋間コンクリートの斜め圧縮束の 反力の一部を負担するとしている ${ }^{9)}$ 。この考え方に基づき, 図 8(a) に示すせん断強度時のせん断力伝達モデルを設定する。試験体は幅 方向 (紙面に垂直方向) にも拘束力を受けているが, 本論では簡単 のため, それを考慮に入れないこととする。トラス機構の有効断面 は, 単純に全幅 $b \times$ 外側主筋間隔 $j_{t}$ とする。領域 BCGFの角度 $\phi$ を 有するコンクリート圧縮束は, 有効圧縮強度 $v \sigma_{B}$ に達しているとす る。かぶりコンクリートは $\mathrm{AE}, \mathrm{DH}$ 面で $\mathrm{PC}$ 鋼棒による一様な圧縮 力を受け, 材端の曲げ圧縮側の $\mathrm{AB}, \mathrm{GH}$ 面では圧縮力とせん断力を 受けるとすれば, 領域AFE, CDHは横方向の一軸圧縮状態で, 領域 $\mathrm{ABF}, \mathrm{CHG}$ は図 8 (b) に示す応力状態となる。せん断強度時には 領域ABF, CHGのコンクリートは有効強度に達しているとし, その 大きさについては簡単のため $\sigma_{A B}$ が $\sigma_{B}$ であるとする。このモデルに よれば, せん断強度 $Q_{s u}$ は次式で表される。

$$
Q_{s u}=b j_{t}\left(\Sigma p_{w} \sigma_{w u}+\sigma_{B} \tan ^{2} \alpha\right) \cot \phi+b d_{c} \sigma_{B} \tan \alpha
$$

ここに, $\Sigma p_{w} \sigma_{w u}=p_{w p c} \sigma_{p c u}+p_{w} \sigma_{t r u}, \sigma_{p c u}$ と $\sigma_{t r u}$ はせん断強度時のPC 鋼棒と横補強筋の応力度, $\tan \alpha=d_{c} / L$ である。なお, $\Sigma p_{w} \sigma_{w u}+\sigma_{B} \tan ^{2} \alpha$ 


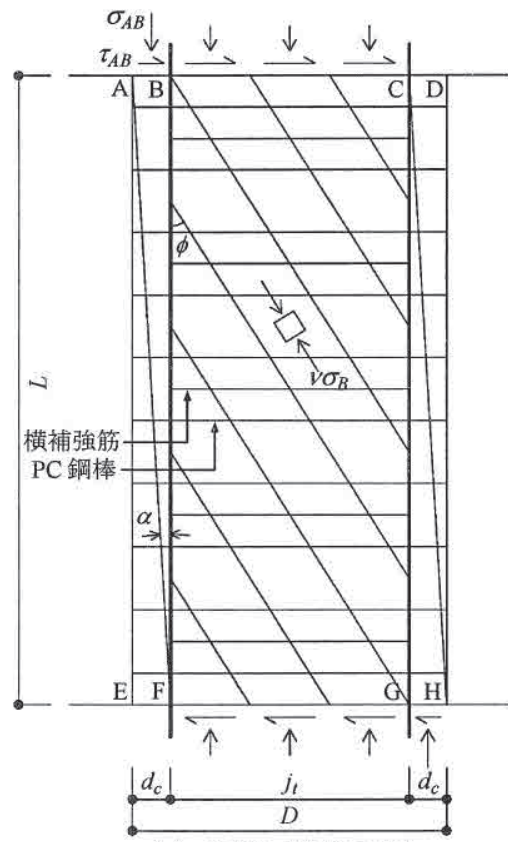

(a) せん断力伝達モデル

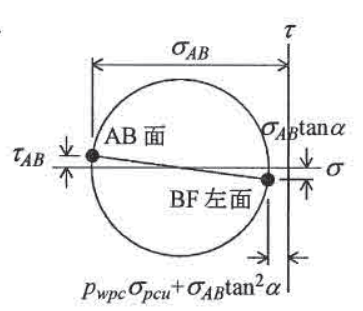

(b) 領域 $\mathrm{ABF}$ の応力円

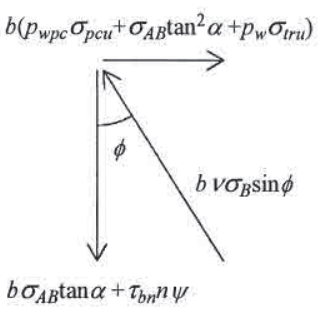

(c) BF右面の力の釣合い (単位長さあたり)

図8 せん断強度算定のモデル

は図 8 (c) より次の条件を満足する必要がある。

$$
v \sigma_{B}=\left(1+\cot ^{2} \phi\right)\left(\Sigma p_{w} \sigma_{w u}+\sigma_{B} \tan ^{2} \alpha\right)
$$

また, $Q_{s u}$ に必要な主筋の付着応力度 $\tau_{b n}$ は図 8 (c) より次式で表 され,これは付着割裂強度 $\tau_{b u}$ 以下でなければならない。

$$
\tau_{b n}=\frac{b}{n \psi}\left\{\left(\Sigma p_{w} \sigma_{w u}+\sigma_{B} \tan ^{2} \alpha\right) \cot \phi-\sigma_{B} \tan \alpha\right\}
$$

\section{3 コンクリート圧縮束の強度と傾斜角}

渡部らは帯筋に初期緊張力を導入すると,初期せん断ひび割れの 水平軸に対する傾斜角が小さくなることに着目し, せん断ひび割れ 角度とアーチ機構角度の関係によりコンクリート圧縮強度の有効係 数 $v$ を設定する方法を提案している10)。本論では能動横拘束によ り, せん断破壊時のPC鋼棒のひずみ度増分は小さくなり, せん断強 度は高くなることに着目し,ひび割れ直交方向のひずみ度の大きさ に依存する $v$ を用いる。本論の試験体のコンクリートは比較的低強 度であること, 式の変形が容易であることから,ここではVecchio

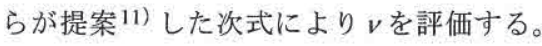

$$
v=\frac{1}{0.8-0.34 \varepsilon_{1} / \varepsilon_{2}}
$$

ただし， $v$ が 1 を超える場合は $v=1$ である。ここに, $\varepsilon_{1}, \varepsilon_{2}$ はひび 割れを含むコンクリートの平均ひずみで表した場合の第 1 , 第 2 主 ひずみ度である。 $\varepsilon_{1}$ は図 9 のひずみ円より, 次式で評価する。

$$
\varepsilon_{1}=\varepsilon_{h u}+\frac{\varepsilon_{h u}-\varepsilon_{2}}{\cot ^{2} \phi}
$$

ここに, $\varepsilon_{h u}$ はせん断強度時におけるコンクリートの平均横ひずみ度 である。 $\varepsilon_{2}$ はコンクリート強度によらず, -0.002 とする。これは本 論の試験体のコンクリート強度の範囲では, 概ね妥当な数値設定と 考えられる。ここで, 式 10 の $\varepsilon_{1}$ を式 11 で評価することは, コンク リート斜め圧縮束の直交方向にひび割れを想定することを意味して いる。また, 式11は縦ひずみ度 $\varepsilon_{v u}$ の状態は考慮していないので, 厳 密にはひずみの適合条件を満たしていない。

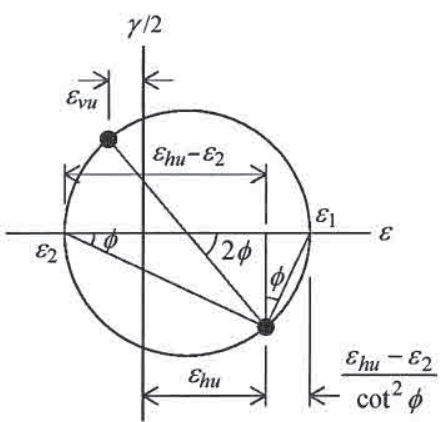

図9 コンクリート圧縮束のひずみ円

式 $8,10,11$ より $\cot \phi$ は, 次式により表される。

$$
\cot \phi=\sqrt{\frac{-B-\sqrt{B^{2}-4 A \cdot C}}{2 A}}
$$

ここに, $A=\left(0.8 \varepsilon_{2}-0.34 \varepsilon_{h u}\right)\left(\sum p_{w} \sigma_{w u}+\sigma_{B} \tan ^{2} \alpha\right), \quad B=\left(1.14 \varepsilon_{2}-0.68 \varepsilon_{h u}\right)$ $\left(\Sigma p_{w} \sigma_{w u}+\sigma_{B} \tan ^{2} \alpha\right)-\varepsilon_{2} \sigma_{B}, C=-0.34\left(\varepsilon_{h u}-\varepsilon_{2}\right)\left(\Sigma p_{w} \sigma_{w u}+\sigma_{B} \tan ^{2} \alpha\right)$ である。なお, $\nu=1$ の場合は, 式 8 よ $\cot \phi=\sqrt{\sigma_{B} /\left(\Sigma p_{w} \sigma_{w u}+\sigma_{B} \tan ^{2} \alpha\right)-1}$ となる。

\section{4 横補強筋と $\mathrm{P}$ C 鋼棒の応力度}

せん断強度時における横補強筋の応力度 $\sigma_{t r u}$ は, そのひずみ度 $\varepsilon_{t r u}$ が $\varepsilon_{h u}$ に等しいと仮定し式13で評価する。柱せいの面の斜めひび割 れは外側主筋間 $\left(j_{t}\right.$ 間) で顕著であり, かぶりコンクリート部では それほどでもない。これより, PC鋼棒の応力度 $\sigma_{p c u}$ は締付け長さが 柱せい $D$ に等しいことを考慮し式14で評価する。

$$
\begin{aligned}
& \sigma_{t r u}=\min \left\{E_{t r} \varepsilon_{h u}, \sigma_{t r y}\right\} \\
& \sigma_{p c u}=\min \left\{E_{p c}\left(\varepsilon_{p c 0}+\varepsilon_{h u} \cdot j_{t} / D\right), \sigma_{p c y}\right\}
\end{aligned}
$$

\section{5 主筋の付着割裂強度}

奥出らは, 高強度横補強筋を用いたRC梁の単調載荷実験におい て, 付着割裂ひび割れよりもせん断ひび割れが顕著な試験体でかな り高い付着応力度を実測し,これはせん断ひび割れによる横補強筋の 引張力の増大により主筋が拘束されたためであると考察している12)。 一方, 細川・前田らの柱の繰返し載荷実験によれば, 割裂ひび割れ の進展により高い主筋拘束力が発生しても, 主筋の付着応力度は単 調載荷の場合よりも小さいことが示されている13)。本論の実験で は, 隅主筋の周辺に付着割裂ひび割れは発生せず,柱のほぼ全長に わたって多数のせん断ひび割れが発生したことにより PC鋼棒のひず み度が大幅に増大した。これより, $\mathrm{PC}$ 鋼棒の引張力の増大は付着割 裂強度の増大に寄与していると考えられる。付着割裂破壊する場合 は割裂ひび割れにより受動拘束が生じるが, 能動側圧が高いほど付 着強度時の受動拘束力は小さくなることがわかっている3)。ここで は, 付着割裂破壊する場合も含め, 横補強筋と $\mathrm{PC}$ 鋼棒による横拘束 力は付着割裂面に対してすべて能動的に作用するとみなし, 主筋の 付着割裂強度を評価する。具体的には, 式 $1 \sim 6$ において主筋能動 拘束応力度 $\sigma_{c 0}$ を能動側圧 $\sigma_{r}$ にかえて $\Sigma p_{w} \sigma_{w u}+\sigma_{B} \tan ^{2} \alpha$ を用いて評 価し, $\tau_{p a}$ は零として付着割裂強度 $\tau_{b u}$ を算定する。

\section{6 計算手順と計算結果の検討}

式 7 に式 $12,13,14$ を代入すると, 式 7 はせん断強度時のコン クリートの平均横ひずみ度 $\varepsilon_{h u}$ のみが未知数の式となる。せん断強度 $Q_{s u}$ は式 9 の $\tau_{b n}$ が付着割裂強度 $\tau_{b u}$ 以下の範囲で $\varepsilon_{h u}$ を決定すれば 算定できる。ここでは, 順次仮定した $\varepsilon_{h u}$ に対する $\tau_{b n}$ と $\tau_{b u}$ を計算 


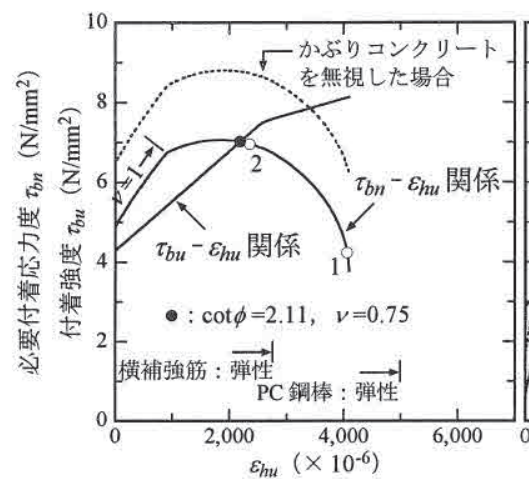

(a) 試験体 M-01

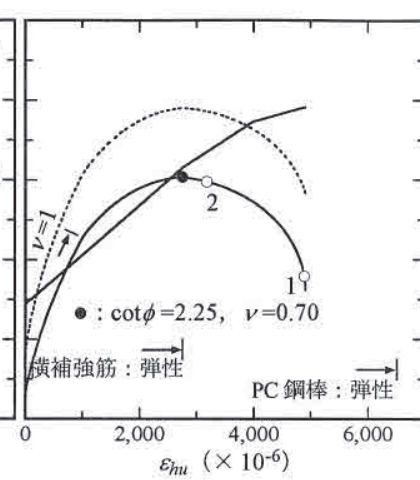

(b) 試験体 M-30

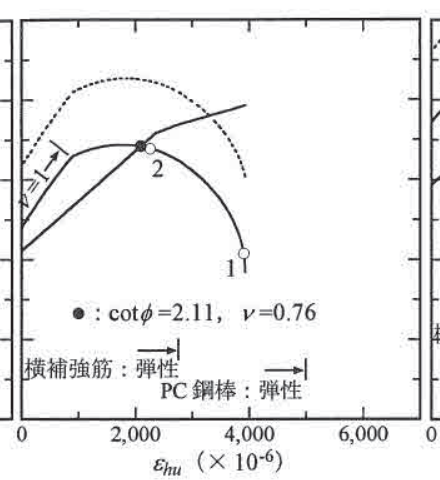

(c) 試験体 M-61

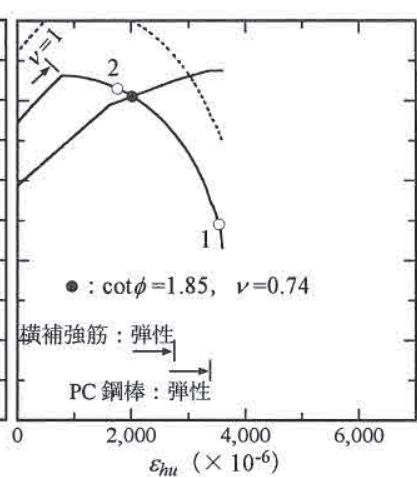

(d) 試験体 M-32

図10 せん断強度時のコンクリートの平均横ひずみ度 $\varepsilon_{h u}$ を順次仮定した場合の $Q_{s u}$ に必要な付着応力度 $\tau_{b n}$ と付着強度 $\tau_{b u}$

し, 両者を比較することにより $\varepsilon_{h u}$ の正解值を求める。

図10に $\varepsilon_{h u}$ を順次仮定した場合の $Q_{s u}$ に必要な付着応力度 $\tau_{b n}$ と付 着強度 $\tau_{b u}$ を示す。本モデルでは軸力の大きさと中段主筋の有無は計 算結果に影響しないため, 試験体M-31, M-61, S-61の結果の違い はコンクリート強度によるものだけである。ここでは, 実験でせん 断破壊した試験体M-61の結果を図 10 (c) に示し, 他の二つの試験

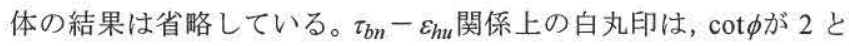
1 であることを示す。また, 横補強筋およびPC鋼棒の降伏に関係な いところで $\tau_{b u}-\varepsilon_{h u}$ 関係に折点があるのは, ある一定以上の横拘束 力がある場合, 隅主筋が引抜け破壊するためである。なお, 図中の 破線はかぶりコンクリートを無視した場合の $\tau_{b n}-\varepsilon_{h u}$ 関係であり， 本論の試験体のように材長が短い場合は,かぶりコンクリートの応 力負担が $\tau_{b n}$ に大きく影響することを示している。

式 7,9 から明らかなように, $Q_{s u}$ は $\tau_{b n}$ と線形関係にある。した がって, 仮定した $\varepsilon_{h u}$ のうち, $\tau_{b n}$ が $\tau_{b u}$ 以下の範囲で最大となるとき の $\varepsilon_{h u}$ が正解值となる。このとき $\tau_{b n}=\tau_{b u}$ であれば, せん断強度 $Q_{s u}$ は主筋の付着割裂強度により決定されており, 付着割裂破壊を考慮 しない場合よりもせん断強度が低く算定される。図中に $\varepsilon_{h u}$ の正解値 と $\tau_{b n}$ を黒丸印で示すとともに, そのときの $\cot \phi$ とを示す。

図 10 (b)，(c)，(d)によれば, PC 鋼棒の補強量が同一でも，能 動側圧が高い試験体ほど $\tau_{b n}$ が高くなっている。これは能動側圧を与 えると $Q_{s u}$ が高く算定されることを示している。

図11に最大荷重の実験值 $Q_{\max }$ (正加力と負加力の平均值) と本モ デルで得られた $Q_{s u}$ の関係を全塑性曲げモーメントに対するせん断 力の計算值 $Q_{m p}$ で基準化して示す。本モデルによる $Q_{s u}$ と $Q_{m p}$ によ り,曲げ降伏が先行した試験体の破壊モードを良く評価できている。 せん断破壊した試験体M-30については, 図10（b）よりわずかなが $ら \tau_{b n}<\tau_{b u}$ であり, 計算結果は実験の破壊モードを説明している。一 方, 試験体 M-61 では図 10 (c) より $\tau_{b n}=\tau_{b u}$ であり， $Q_{s u}$ は $\tau_{b u}$ によ り決定されている。しかし, $Q_{s u}$ と付着割裂破壊を考慮しない場合の せん断強度の差は $0.4 \%$ あるる。た, せん断破壊した試験体M-30, M-61のせん断強度計算値は実験値よりも若干高めである。

図12にせん断破壊した試験体M-30, M-61について, 実験により 得られた $\mathrm{PC}$ 鋼棒のひずみ度と本モデルによる $Q_{s u}$ 時の $\mathrm{PC}$ 鋼棒ひず み度を示す。計算値は実験の最大荷重時のひずみ度の平均値程度に なっている。また, 計算值ではPC鋼棒に初期ひずみを導入するとせ ん断強度時のひずみ度増分が小さくなっており,軸力の違いはある が実験結果と同じ傾向を示している。

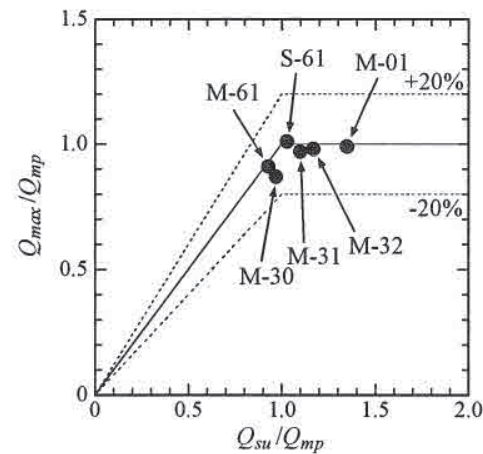

図11 本論のモデルによる破壊モードと最大荷重の評価精度

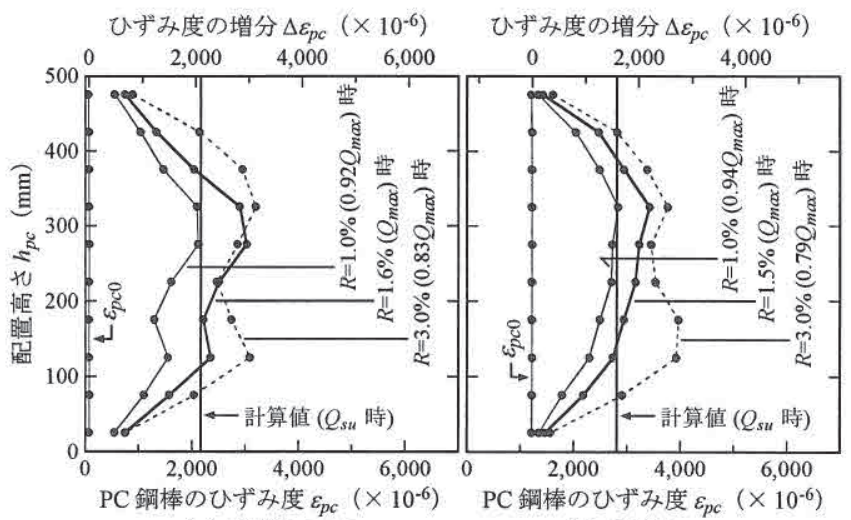

(a) 試験体 M-30

(b) 試験体 M-61

図12 $\mathrm{PC}$ 鋼棒ひずみ度 $\varepsilon_{p c}$ の実験值と本論のモデルによる計算値

以上のように,本モデルにより実験の破壊モードを概ね評価する ことができた。また, 能動側圧を与えると,せん断強度時のPC鋼棒 のひずみ度増分は小さくなり, せん断強度は増大する傾向を表すこ とができた。しかし, せん断強度の計算值は実験值よりも若干高め であった。この理由の一つはトラス機構の有効断面の取り方にある と考えられる。本モデルでは全幅を有効としたが,これよりも小さ い断面を設定すれば, せん断強度を低く算定することになり,せん 断強度算定の精度向上が期待できる。これについては, 本モデルで 仮定したコンクリート圧縮強度の有効係数, 主筋の付着割裂強度に 関する妥当性の検討も含め, 今後の検討が必要である。

\section{7 かぶりコンクリートの効果を勒性指針式に適用した場合}

前節までの検討により,かぶりコンクリートの応力負担により主 筋の付着力が緩和される効果, せん断ひび割れに起因する受動横拘 束により主筋の付着割裂強度が増大する効果があると考えれば, 本 
表4＼cjkstart試験体の諸元とかぶりコンクリートの効果を䩔性指針式に適用した場合の計算値

\begin{tabular}{|c|c|c|c|c|c|c|c|c|c|c|c|c|c|c|c|c|}
\hline \multirow[b]{2}{*}{ 試験体 } & \multicolumn{7}{|c|}{ 諸元 } & \multicolumn{3}{|c|}{ 実験結果 } & \multicolumn{6}{|c|}{ 計算結果 } \\
\hline & 主筋量 & $M / Q D$ & $\begin{array}{l}p_{w} \\
(\%)\end{array}$ & $\begin{array}{r}p_{w p c} \\
(\%)\end{array}$ & $\begin{array}{c}\sigma_{r} \\
\left(\mathrm{~N} / \mathrm{mm}^{2}\right)\end{array}$ & $\frac{\sigma_{0}}{\sigma_{B}}$ & $\begin{array}{c}\sigma_{B} \\
\left(\mathrm{~N} / \mathrm{mm}^{2}\right)\end{array}$ & $\begin{array}{l}\text { 破壊 } \\
\text { モード }\end{array}$ & $\begin{array}{c}\mathrm{PC} \text { 鋼棒 } \\
\text { 降伏の } \\
\text { 有無 }^{* 1}\end{array}$ & $\frac{Q_{\max }}{Q_{m u}}$ & $\frac{Q_{s u}}{Q_{m u}}\left({ }^{*} 2\right)$ & $\frac{Q_{b u}}{Q_{m u}}$ & $\frac{Q_{s c}}{Q_{m u}}$ & $\begin{array}{c}\text { 最大荷重 } \\
\text { 決定破壊 } \\
\text { モード } \\
\end{array}$ & $Q_{s u}$ 比 & $Q_{b u}$ 比 \\
\hline 2: M-30 & 12-D13 & 1.0 & 0.10 & 0.37 & 0.06 & 0.16 & 19.4 & S & なし & 0.91 & $1.03(16)$ & 0.73 & 0.45 & B & 1.02 & 1.16 \\
\hline 3: M-31 & 12-D13 & 1.0 & 0.10 & 0.37 & 0.92 & 0.15 & 21.1 & $F y-S$ & なし & 1.04 & $1.08(16)$ & 0.87 & 0.56 & B & 1.02 & 1.17 \\
\hline 4: M-32 & 12-D13 & 1.0 & 0.10 & 0.37 & 1.85 & 0.15 & 20.6 & $F y-S$ & なし & 1.05 & $1.07(16)$ & 0.98 & 0.66 & B & 1.02 & 1.17 \\
\hline 5: M-61 & 12-D13 & 1.0 & 0.10 & 0.37 & 0.92 & 0.34 & 18.6 & S & なし & 1.02 & 0.94 (16) & 0.77 & 0.68 & B & 1.02 & 1.17 \\
\hline 6: S-61 & 8-D13 & 1.0 & 0.10 & 0.37 & 0.92 & 0.33 & 19.1 & Fy $-S$ & なし & 1.08 & $1.00(16)$ & 0.82 & 0.71 & B & 1.02 & 1.17 \\
\hline 7: R99S-P105 & 12-D10 & 1.0 & 0.08 & 0.09 & 0.42 & 0.20 & 20.7 & S - Bs & 有 & 0.82 & $0.81 \quad(15)$ & 0.94 & 0.71 & $\mathrm{~S}$ & 1.01 & 1.23 \\
\hline 8: R98M-P105 & 12-D10 & 1.5 & 0.08 & 0.09 & 0.42 & 0.20 & 27.4 & $\mathrm{~S}$ & 有 & 1.16 & $1.08(15)$ & 1.31 & 1.10 & $\mathrm{~F}$ & 0.98 & 1.20 \\
\hline 9: R99M-P150 & 12-D13 & 1.5 & 0.08 & 0.06 & 0.30 & 0.20 & 18.4 & $\mathrm{~S}-\mathrm{Bs}$ & 有 & 0.92 & $0.72(15)$ & 0.90 & 0.74 & $\mathrm{Sc}$ & 0.98 & 1.17 \\
\hline 10: R99M-P105 & 12-D13 & 1.5 & 0.08 & 0.09 & 0.42 & 0.20 & 18.4 & S - Bs & なし & 0.88 & $0.86(15)$ & 0.93 & 0.76 & $\mathrm{~S}$ & 1.01 & 1.17 \\
\hline 11: R99M-P150H & 12-D13 & 1.5 & 0,08 & 0.06 & 0.30 & 0.20 & 26.8 & $\mathrm{~S}-\mathrm{Bs}$ & 有 & 0.89 & $0.69(15)$ & 0.98 & 0.80 & $\mathrm{Sc}$ & 0.95 & 1.19 \\
\hline 12: R99M-P150L & 12-D13 & 1.5 & 0.08 & 0.06 & 0.30 & 0.20 & 14.2 & $\mathrm{~S}-\mathrm{Bs}$ & なし & 0.70 & $0.74(15)$ & 0.84 & 0.69 & $\mathrm{~S}$ & 1.00 & 1.16 \\
\hline 13: R99M-P41'L & 12-D13 & 1.5 & 0.08 & 0.45 & 2.19 & 0.20 & 14.2 & Bs & なし & 0.92 & $1.17(17)$ & 1.17 & 1.03 & $\mathrm{~F}$ & 1.02 & 1.12 \\
\hline 15: R99L-P150 & 12-D13 & 2.0 & 0.08 & 0.06 & 0.30 & 0.20 & 21.2 & $\mathrm{~S}-\mathrm{Bs}$ & なし & 1.01 & $0.90 \quad(15)$ & 1.16 & 1.02 & $\mathrm{~F}$ & 0.97 & 1.15 \\
\hline 16: R98S-P41 & 12-D10 & 1.0 & 0.08 & 0.22 & 1.08 & 0.20 & 31.6 & $\mathrm{FC}$ & 有 & 1.12 & $1.17(16)$ & 1.10 & 0.84 & $\mathrm{~F}$ & 1.06 & 1.26 \\
\hline 17: R98S-P41' & 12-D10 & 1.0 & 0.08 & 0.45 & 2.19 & 0.20 & 31.6 & FC & 有 & 1.17 & $1.36(16)$ & 1.25 & 0.98 & $\mathrm{~F}$ & 1.04 & 1.28 \\
\hline 18: R99S-P41'H & 12-D10 & 1.0 & 0.08 & 0.45 & 2.19 & 0.20 & 30.9 & FC & なし & 1.17 & $1.35(16)$ & 1.24 & 0.98 & $\mathrm{~F}$ & 1.04 & 1.27 \\
\hline 19: R98M-P65N & 12-D10 & 1.5 & 0.08 & 0.14 & 0.00 & 0.20 & 27.4 & $\mathrm{~F}-\mathrm{Bs}$ & 有 & 1.20 & $1.43 \quad(15)$ & 1.22 & 0.99 & $\mathrm{~F}$ & 1.03 & 1.20 \\
\hline
\end{tabular}

備考) F : 曲げ破壊, S : せん断破壊, Fy - S : 曲げ降伏後のせん断破壊, S - Bs : せん断破壊（その後, 履歴ループの逆 S 字化が顕著なもの), Bs：付着すべり破壊,

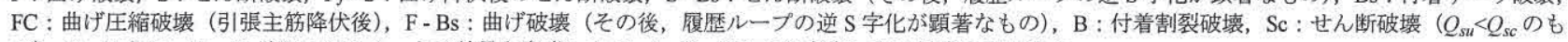
の), $Q_{s u}$ 比と $Q_{b u}$ 比 : かぶりコンクリートの効果を考慮した $Q_{s u}$ と $Q_{b u}$ のそれを考慮しない場合に対する比

${ }^{*} 1$ : 実験終了までの降伏の有無を示す（最大荷重時には降伏していない）。 ${ }^{2}$ : 括弧内はせん断強度が算定された式番号を示す。

論の試験体で付着割裂破壊が先行しなかったことを概ね説明するこ とができた。本節では,かぶりコンクリートの応力負担の効果を勒 性指針式5)に適用した場合の破壊モードと最大荷重の評価精度を検 討する。せん断ひび割れに起因する受動横拘束により主筋の付着割 裂強度が増大する効果は余力と考え, 付着割裂強度はPC鋼棒の初期 緊張力に基づいて評価する。

表 4 に検討に用いる試験体の概要を示す。上部の 6 体が本論の試 験体で, 7 段目からの13 体は文献 14）の試験体である。実験の破 壊モードで分類すると, 曲げ降伏が先行した試験体 (F, Fy-S, FC, F-Bs）が計 8 体，せん断破壊が先行した試験体（S, S-Bs）が計 10 体, 付着すべり破壊した試験体 (Bs) が 1 体である。ここで, 付着 すべり破壊した試験体は, $\sigma_{B}$ が $14.2 \mathrm{~N} / \mathrm{mm}^{2}$ の柱を多量のPC鋼棒で 補強したもの (試験体13) で, 最大荷重時にせん断ひび割れも付着 割裂ひび割れもないが, 履歴ループの逆 $\mathrm{S}$ 字化が顕著で最大荷重 $Q_{\max }$ が曲げ終局強度時せん断力 $Q_{m u}$ を下回った試験体である。

せん断強度 $Q_{s u}$ は, 式 $15,16,17$ による算定值の最小值とする。

$$
\begin{aligned}
Q_{s u} & =2 \sigma_{l} b_{e} j_{e}+\left(v \sigma_{B}-\frac{5 \sigma_{l}}{\lambda}\right) \frac{b j_{e}}{2} \tan \theta+b d_{e} \sigma_{B}\left(d_{e} / L\right) \\
Q_{s u} & =\sigma_{l} b_{e} j_{e} \cot \phi+b d_{e} \sigma_{B}\left(d_{e} / L\right) \\
Q_{s u} & =\frac{\lambda v \sigma_{B}}{2} b_{e} j_{e}+b d_{e} \sigma_{B}\left(d_{e} / L\right)
\end{aligned}
$$

ここに, $\sigma_{l}=\left\{p_{w} \sigma_{t r y}+p_{w p c} \sigma_{p c y}+\sigma_{B}\left(d_{e} / L\right)^{2}\right\} b / b_{e}, b_{e}$ は横補強筋のせん 断力直交方向一の芯々間距離, $j_{e}$ は横補強筋のせん断力方向一の芯々 間距離, $v=0.7-\sigma_{B} / 200\left(\sigma_{B}: \mathrm{N} / \mathrm{mm}^{2}\right), \tan \theta=\left(\sqrt{L^{2}+j_{e}{ }^{2}}-L\right) / j_{e}, d_{e}$ は横補強筋の芯から測ったコンクリートのかぶり厚さ $=\left(D-j_{e}\right) / 2$, $L$ は材長, $\cot \phi=\sqrt{\lambda v \sigma_{B} / \sigma_{l}-1}$ である。また, トラス機構の有効係 数 $\lambda$ は 1.0 とする。式 15 は第 1 項がトラス機構の負担せん断力, 第 2 項がアーチ機構, 第 3 項がかぶりコンクリートの負担せん断力 である。かぶりコンクリートの応力負担は第 1 項と第 3 項で考虑 したので, 第 2 項のアーチ機構の負担せん断力は, $D$ を $j_{e}$ に置き換
えることにより,かぶりコンクリート部を除いたものとなっている。 また, 横補強筋とPC鋼棒が降伏し,アーチ機構が存在しない場合の せん断強度は, $\cot \phi$ を計算する方法 (式16) で算定する。

付着割裂破壊の影響を考慮したせん断強度 $Q_{b u}$ は, 式18により算 定し, 式17によるせん断力を超えないとする。

$$
Q_{b u}=T_{x} j_{e}+\left(v \sigma_{B}-\frac{2.5 T_{x}}{\lambda b_{e}}\right) \frac{b j_{e}}{2} \tan \theta+b d_{e} \sigma_{B}\left(d_{e} / L\right)
$$

ここに, $T_{x}=\tau_{b u} n \psi+b \sigma_{B}\left(d_{e} / L\right), n$ と $\psi$ は外側主筋の本数と周長で ある。主筋の付着割裂強度 $\tau_{b u}$ は, 能動側圧 $\sigma_{r}$ を用い式 $1 \sim 6$ で算 定する。その他の変数の意味は, 式 15 に同じである。

表 4 にかぶりコンクリートの効果を考虑した $Q_{s u} \cdot Q_{b u}$ と, せん断 ひび割れ強度 $Q_{s c}$ の計算值を曲げ終局強度時せん断力 $Q_{m u}$ で基淮化し たものを示す。ここで, $Q_{s c}$ の計算値は次式によった。

$$
Q_{s c}=\sqrt{\left(\sigma_{T}+\sigma_{0}\right)\left(\sigma_{T}+\sigma_{r}\right)} b \cdot D / \kappa
$$

ここに, $\sigma_{T}$ はコンクリートの引張強度 $=0.33 \sqrt{\sigma_{B}}, \kappa$ は形状係数 $=1.5$ である。なお, 軸方向応力度 $\sigma_{0}$ と能動側圧 $\sigma_{r}$ は圧縮を正とする。

表 4 の $Q_{s u}$ 比と $Q_{b u}$ 比は, かぶりコンクリートの効果を考慮した $Q_{s u}$ と $Q_{b u}$ の, それを考虑しない場合に対する比を示す。かぶりコン クリートの効果は $Q_{s u}$ にはあまり影響せず $\left(Q_{s u}\right.$ 比 $\left.=0.95 \sim 1.06\right)$, アーチ機構が卓越する場合はアーチのせいが $D$ から $j_{e}$ となる影響が 強く表れるため, むしろせん断強度が若干低く算定される試験体があ る。一方, $Q_{b u}$ はかぶりコンクリートの効果を考慮すると増大し, $Q_{b u}$ 比で $1.12 \sim 1.28$ となっている。

図13に最大荷重の実験値 $Q_{\max }$ とせん断強度の計算値を $\min \left(Q_{s u}, Q_{b u}\right)$ とした場合の関係を $Q_{m u}$ で基準化して示す。中抜きの記号 $(O, \square)$ は最大荷重決定の破壊モードが実験と計算で一致している試験体を 示し, 中塗りの記号 (十, 圆，は）はそうでないものを示す。なお, $Q_{s u}<Q_{s c}$ である試験体 $8,9,11,15$ (表 4 参照) は除いて示してい 


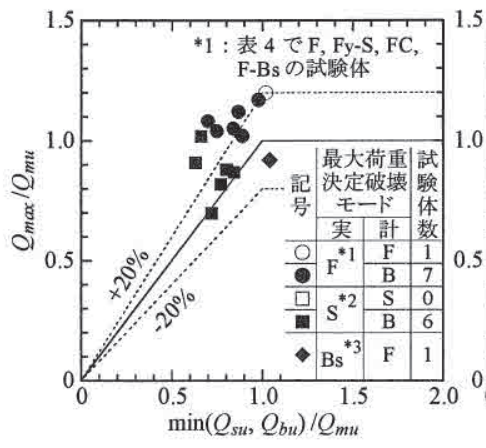

（a）かぶりの効果を考慮しない場合

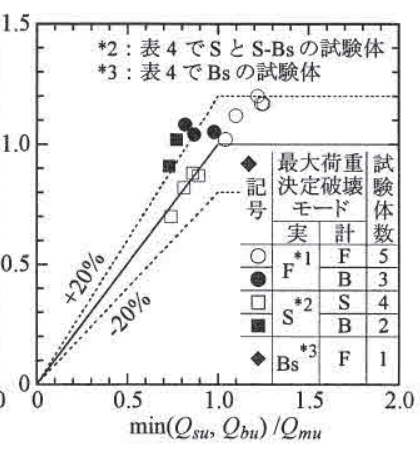

（b）かぶりの効果を考慮した場合 図13 破壊モードと最大荷重の評価精度

る。図 13 (a) に示すように,かぶりコンクリートの効果を考虑し ない場合は, ほとんどの試験体の計算值が $Q_{b u}$ で決定し(破壊モー ド : B), 最大荷重の実験值を過小に評価する傾向がある。

一方, かぶりコンクリートの効果を考慮すると, 図 13 (b) に示 すように, $Q_{b u}$ の増大により実験と計算の破壊モードが一致する試 験体が多くなるが, 計算值が $Q_{b u}$ で決定し, 最大荷重の実験值を依 然として過小に評価する試験体 (一，目) が計 5 体ある。これらの 試験体は曲げ降伏またはせん断破壊が先行したものであり,付着割 裂破壊は生じていない。以上より, 式 18 の $Q_{b u}$ 算定式はかぶりコン クリートの効果を考慮することにより下界定理に基づく勒性指針式 をより真の強度に近い評価を与えるように上方修正したものである が, まだ低め (安全側) の評価を与えると考えられる。

なお, 印の試験体は計算では曲げ破壊 $\left(Q_{b u} / Q_{m u}=1.17\right)$ である が, $Q_{\max }$ は $Q_{m u}$ を下回っている。この試験体（表 4 の試験体 13）は 付着すべり破壊したと報告されているが， $\tau_{b u} / \tau_{f}$ は 1.24 であり顕著 な付着すべりは生じていないと考えられる。これより,この試験体は 基本的には曲げ破壊であるが, 主筋のスタブ内における定着すべりの 影響により $Q_{\max }$ が $Q_{m u}$ を下回ったのではないかと考えられる。

図13(b)によれば, 口の記号で示されるように, $Q_{s u}$ はせん断破 壊した試験体の最大荷重を良好に評価している。表 4 の $Q_{s u}<Q_{s c}$ の試験体を除いた 6 体のせん断破壊先行試験体では, $Q_{s u}$ に対する $Q_{\max }$ の比は $0.88 \sim 1.08$ で, 平均值 0.99 , 変動倸数 0.06 となる。し かし， $Q_{s u}$ は式15あるいは式16で算定され，これはPC鋼棒が降伏 することを意味しているが, 実験では降伏していない。今後, 実現 象も説明できる実用的なせん断強度算定式の開発が望まれる。

\section{6. まとめ}

本論では, 外部PC鋼棒により横補強されたRC柱の付着割裂破壊 の影響を受けるせん断強度の把握を目的とし, 能動側圧の大きさ, 軸力の大きさ, 中段主筋の有無を変数とした柱の曲げせん断実験を 行った。また, 実験結果を基に付着割裂破壊の影響を受けるせん断 強度算定法の検討を行った。その結果を以下にまとめる。

1）外部PC鋼棒がある場合の主笳の付着割裂強度を勒性保証型耐震 設計指針式に適用することにより，付着割裂破壊先行の実験を計 画した。しかし，いずれの試験体も付着割裂破壊しなかった。こ れは, 曲げ強度やせん断強度が計算值よりも特に低かったわけで はなく, 付着割裂破壊の影響を受けるせん断強度が計算値よりも 高かったためである。

2）付着割裂破壊の影響を受けるせん断強度が計算値よりも高かった

要因は,かぶりコンクリートの応力負担により主筋の付着力が緩 和されること,また,付着割裂ひび割れに先行して多数発生した せん断ひび割れに起因するPC鋼棒と横補強笳の受動拘束により, 主筋の付着割裂強度が増大したことにあると考えられる。

3）かぶりコンクリートの効果を考虑できるモデルを勒性保証型耐震 設計指針式に適用すれば, 付着割裂破壞の影響を考慮したせん断 強度の計算値は安全側の範囲で増大することがわかった。なお, かぶりコンクリートの効果を考慮したモデルと通常のモデルは, 本研究に引用した試験体のせん断強度の算定に関してはほとんど 同じ結果を与えた。

本論の範囲では, 付着割裂破壊が生じた実験資料による算定式の 妥当性の検証はできていないため, 今後検証が必要である。また, せん断ひび割れに起因する受動横拘束により付着割裂強度が増大す る効果は余力と考え無視したが,より精度の高い算定式を提案する ためには考虑する必要があると考えられる。実現象も説明できるせ ん断強度算定式の開発とあわせて,今後の検討課題としたい。

\section{謝辞}

本研究の計画にあたり故 吉村浩二先生 (元大分大学教授)から有 益な助言を頂戴した。実験で用いたPC鋼棒は高周波熱錬 (株)より 提供して頂いた。また, 日本学術振興会の科学研究費補助金 (基盤 研究 B (一般), 課題番号 : 14350306, 代表者 : 山川哲雄 琉球大 学教授)を受けた。ここに記して謝意を表します。

\section{参考文献}

1) E. G. Burdette and H.K. Hilsdorf: Behavior of Laterally Reinforced Concrete Columns, Journal of the Structural Division, ASCE, pp. 587-602, 1971. 2

2) 中田幸造, 日高桃子, 古川照, 山川哲雄, 崎野健治: 緊張力を導入したPC 鋼棒により外部横補強された鉄筋コンクリート柱の応力ひずみ関係, 日本 建築学会構造系論文集, 第 600 号, pp. $147 \sim 153,2006.2$

3）黒木正幸, 菊池健児, 崎野健治, 山川哲雄 : 外部 PC 鋼棒により横補強さ れた R C 柱における異形主筋の付着割裂強度, 日本建築学会構造系論文集, 第 603 号, pp. $131 \sim 138,2006.5$

4) 国分正胤, 岡村甫 : 太径鉄筋の使用に関寸る研究, 土木学会論文報告集, 第 202 号, pp. $103 \sim 113,1972.6$

5) 日本建築学会編 : 鉄筋コンクリート造建物の勒性保証型耐震設計指針・同 解説, pp. $142 \sim 158$, pp. $175 \sim 190,1999.8$

6) 日本建築学会編 : 鉄筋コンクリート構造計算規準・同解説, 1991一部改, pp. $604 \sim 615,1991.4$

7) 飯星力, 田中仁史 : 連続瀻維で横補強したコンクリート部材の曲げせん断 性状一付着割裂破壊時のせん断耐力と変形性能の評価一, 日本建築学会構 造系論文集, 第 603 号, pp. 115 121，2006.5

8) T. Hitaka, K. Sakino, T. Yamakawa, and A. Furukawa: Compressive and Flexural Behavior of RC Columns Laterally Prestressed by High-strength Steel Bars, International Symposium on Confined Concrete (ACI SP-238), pp. 429-445, 2006

9) 市之瀬敏勝: RC部材の危険断面近傍でのトラス機構, 日本建築学会構造系 論文集，第 475 号, pp. $129 \sim 135,1995.9$

10）渡部洋, 河合繁, 香取慶一, 篠原保二, 林靜雄 : 横方向ブレストレスによ る鉄筋コンクリート柱のせん断ひび割れ制御と終局耐力の評価, 日本建築 学会構造系論文集, 第 577 号, pp. 109 116, 2004.3

11) Frank J. Vecchio and Michael P. Collins: The Modified Compression-Field Theory for Reinforced Concrete Elements Subjected to Shear, Journal of the American Concrete Institute, V. 83, No. 2, pp. 219-231, 1986. 3-4

12）奥出久人, 高木仁之, 狩野芳一:付着割裂破壊に支配される梁のせん断耐力, コンクリート工学年次論文報告集, 第 11 巻, 第 2 号, pp. $81 \sim 86,1989.6$

13）細川洋治, 前田匡樹, 小谷俊介, 青山博之: 鉄筋コンクリート部材の付着 割裂破壞性状に関する実験研究（その 1 実験概要, その 2 実験結果の 検討), 日本建築学会大会学術講演梗概集, C, pp. $215 \sim 218,1993.9$

14）山川哲雄, 鴨川茂義, 倉重正義 : PC鋼棒にプレストレスを導入して外帯笳 状に耐震補強した RC柱の性能と設計, 日本建築学会構造系論文集, 第5 537 号, pp. $107 \sim 113,2000.11$ 